\title{
Party System Fragmentation in Indonesia: The Subnational Dimension
}

\author{
Dirk Tomsa
}

In this article I analyze the extent and causes of party system fragmentation in Indonesia's provincial and district parliaments. Focusing on the results of the first three post-Suharto elections in 1999, 2004, and 2009, I first highlight that local-level fragmentation is not only generally higher than national-level fragmentation but also that it has consistently increased over the three elections and that fragmentation has been particularly high in Eastern Indonesia. I then explain these three trends as a result of three main factors: First, electoral institutions applied between 1999 and 2009 facilitated fragmentation and poor party system institutionalization, mainly due to the introduction of an open list system in 2009 and the absence of a parliamentary threshold at the local level. Second, low levels of party institutionalization progressively individualized local party politics and made it normal for candidates to switch to smaller parties if it suited their interests, thereby exacerbating fragmentation. Third, electoral campaigning for local parliaments has been dominated by traditional methods based on personal relationships and networks rather than lavish public relations campaigns with expensive TV ads, further reinforcing the effects of the first two factors. KEYWORDS: Indonesia, party system, parties, elections, democratization, democracy, institutionalization, local politics

FIFTEEN YEARS AFTER THE FALL OF SUHARTO, INDONESIA'S DEMOCRATIzation process has stalled. Endemic corruption, religious intolerance, and environmental destruction are just some of the problems that have cast a shadow on the country's recent political development. For large parts of the Indonesian public, the main culprits for these and other problems are sitting in the country's parliaments. Time and time again, public opinion surveys have singled out political parties as the least trustworthy political organizations in the country. The media also like to highlight the various shortcomings of political parties, especially their "questionable work ethic and poor legislative productivity" (Johnson Tan 2013, 83). Another frequently heard 
lament is that there are too many parties and that they lack a strong enough mandate to properly fight for the people's aspirations, forcing them to build largely inefficient and unstable coalitions that are mostly preoccupied with trying to manage their internal affairs rather than crafting public policy. ${ }^{1}$

To some extent, these complaints are warranted. Indonesian party politics is indeed characterized by a sometimes confusing mix of competition and collusion that makes governance exceedingly difficult. Most studies that seek to conceptualize this phenomenon focus on national-level party politics (Ambardi 2008; Johnson Tan 2006; Slater 2004), but this national focus disguises the actual depth of the problem. In decentralized Indonesia, key political dynamics occur at the local level (Hadiz 2010), yet the role of political parties in local politics remains surprisingly understudied. Therefore, with this article I aim to make a new contribution to our understanding of local party politics in Indonesia by examining the format and institutionalization of local party systems in the period prior to the 2014 election.

Building on conceptual parameters developed by Lindberg (2007) in his work on African party systems, I begin the article by highlighting three key features of local party systems in Indonesia. First, party system institutionalization at the provincial and district levels is generally much weaker than at the national level. Second, many local party systems exhibit a clear linear trend toward increasing fragmentation over time in the period 1999-2009, a development that stands in contrast to dynamics in the national party system. Third, despite this linear trend over time, there is considerable spatial variation in the level of fragmentation of local party systems. Provincial party systems in Java and Sumatra, for example, tend to be much better institutionalized than those in Eastern Indonesia.

In the second part of the article I discuss potential explanations for these phenomena. I focus on three interconnected factors, all of which have had a significant impact on the composition of local parliaments. First, an analysis of the changing nature of Indonesia's electoral institutions helps us understand both the general differences between the national and local party systems as well as the diverging trends at these levels over time. Second, low levels of party institutionalization-already pervasive at the national level but often exacerbated at the local level by a mixture of poor top-down party management, pervasive clientelism, and inadequate grassroots development-have individualized local party politics and eroded the potential for parties to build loyal voter bases, thereby contributing to 
the high levels of fragmentation in local party systems. Significantly, poor party institutionalization has not only reinforced the effects of the electoral institutions, but it also helps account for the spatial variation in local party system fragmentation as it is much more prevalent in Eastern Indonesia than in Java and Sumatra, where historical, socioeconomic, and sociocultural factors have combined to facilitate more substantial party development than in Sulawesi, Maluku, and Papua. Finally, the third point is that in contrast to the national level, where lavish public relations campaigns with expensive TV ads have become commonplace, local party politics is still dominated by more traditional campaign strategies as candidates tend to seek electoral support primarily on the basis of personal networks rather than identification with a political party.

Taken together, the trends outlined in this article help to provide a better understanding of local party politics in contemporary Indonesia. To be sure, some aspects of fragmentation will be reversed in the 2014 election due to new electoral rules that have led to the disqualification of many small parties in the run-up to that poll. For example, the absolute number of parties will inevitably decline in some districts simply because there will be fewer parties allowed to compete in the 2014 election than had actually won seats in the 2009 election. But as will be shown below, Lindberg's framework makes it clear that fragmentation is a multidimensional process and while the absolute number of parties may decline in some districts, other elements of fragmentation, such as volatility or the number and percentage of parties thrown out of a legislature from one election to the next, are likely to remain high in many districts.

\section{Measuring Party System Stability in Indonesia}

A stable party system comprised of well-organized parties that are deeply rooted in society is widely regarded as a key component of a democratic political system. ${ }^{2}$ Though analytically distinct, the twin concepts of party institutionalization and party system institutionalization are closely connected; the better institutionalized the parties, the higher the likelihood that the party system will also institutionalize as interaction between parties becomes more predictable and regular (Randall and Svåsand 2002; Hicken and Kuhonta 2011). While party institutionalization is notoriously difficult to measure, party system institutionalization lends itself to relatively systematic analysis, at least if it is equated with stability and narrowed down to quan- 
tifiable variables such as volatility or the effective number of parties. Since both of these indicators can be calculated by using well-established formulae, ${ }^{3}$ they provide easily comparable indexes that contain important clues about the degrees of fragmentation and fluidity of party systems.

Many scholars, however, argue that party system institutionalization is a more complex concept. Some of the most influential analytical frameworks like those developed by Mainwaring and Scully (1995) or Randall and Svåsand (2002) regard stability as only one of several factors constituting party system institutionalization. Others have suggested considering completely different factors more closely associated with individual actors rather than parties, for example, the percentage of independent candidates (Protsyk and Wilson 2003) or levels of candidate party switching (Shabad and Słomczyński 2004). Yet another approach is to focus on stability as the key criterion but to broaden the conceptual dimension of stability to more than just volatility and the effective number of parties. Lindberg's (2007) comparative analysis of twenty-one different African party systems uses such an approach. Though he actually excludes the effective number of parties because he regards this indicator as "unreliable in classifying party systems in Africa" (Lindberg 2007, 220), his multifaceted concept of stability represents one of the most comprehensive yet measurable approaches to party system institutionalization. Apart from Pedersen's volatility index, he also uses seven other indicators that help to understand stability in a party system in a more holistic fashion:

1. The absolute number of parties in the legislature

2. The number of new parties in the legislature

3 . The share (percentage) of new parties in the legislature

4. The number of parties voted out of the legislature

5. The share (percentage) of parties voted out of the legislature

6 . The share (percentage) of seats in the legislature occupied by the largest party

7. The share (percentage) of seats in the legislature held by the runner-up

8. Pedersen's volatility index

I adopt Lindberg's framework but complement it with Laakso and Taagepera's (1979) effective number of legislative parties (ENLP) index to test whether Lindberg's $(2007,220)$ claims of unre- 
liability are also true for the local Indonesian context. All in all, therefore, the following analysis is based on nine indicators that provide a sound conceptual basis for the creation of a comprehensive picture of levels of party system (in)stability in some of Indonesia's subnational parliaments.

Before proceeding, a quick look at some trends in the national party system is necessary to contextualize the extent of fragmentation at the local level. In Indonesia's national parliament (Dewan Perwakilan Rakyat, DPR), the effective number of legislative parties after the 2009 election was 6.2, down from 7.1 in the 2004-2009 parliament, but still higher than the 5.4 of the 1999-2004 parliament when the five biggest parties accounted for more than 80 percent of the vote (see Table 1; Tomsa 2008, 187). ${ }^{4}$ Volatility based on legislative seats was moderately high at 25.9 , but has remained fairly constant since the previous election when it was 26.3 .

The consistent decline in the absolute number of legislative parties and the decline in the effective number of legislative parties in 2009 , along with the fact that volatility has remained virtually unchanged and the national party system now has what Wolinetz (2006) called "a discernible core" of six parties, all indicate that the national party system is, contrary to public perceptions in Indonesia, actually stabilizing (Mietzner 2009a; Tomsa 2010). In fact, even before the 2009 election Mietzner (2008) had already argued that there were elements of stabilization discernible in the party system. For him, the main reasons behind the relative stability of the contemporary Indonesian party system, as opposed to the only other democratic Indonesian party system of the 1950 s, are the comparatively low levels of ideological polarization and the centripetal nature of interparty competition. However, this lack of ideological polarization has not prevented the party systems at the provincial and district levels from becoming heavily fragmented over the years. Indeed, as will

Table 1 Number of Legislative Parties in Indonesia's House of Representatives

\begin{tabular}{lccc}
\hline & $1999-2004$ & $2004-2009$ & $2009-2014$ \\
\hline $\begin{array}{c}\text { Absolute number of } \\
\text { legislative parties (ANLP) }\end{array}$ & 21 & 16 & 9 \\
$\begin{array}{c}\text { Effective number of } \\
\text { legislative parties (ENLP) }\end{array}$ & 5.4 & 7.1 & 6.2 \\
\hline
\end{tabular}


be demonstrated below, many party systems at the subnational level are extremely unstable and fluid. To illustrate this, in the following section I will utilize the methodological tools outlined above, beginning with an analysis of provincial-level party systems in 2004 and $2009^{5}$ and then proceeding to an analysis of some selected districtlevel party systems between 1999 and 2009.

\section{Party System Fragmentation at the Subnational Level}

At the provincial level, party systems are certainly more fragmented and fluid than at the national level, but the trend here is still relatively moderate. For example, the average volatility per province based on parliamentary seats after the 2009 election was 30.8 while the average effective number of legislative parties reached 7.95. What needs to be noted though is that these average figures mask significant discrepancies between individual provinces, especially in regard to the number of parties-absolute as well as effective-represented in the provincial legislatures. Bali, for example, has a remarkably low ENLP of just 3.6, while West Papua has a very high 13.6. In general, most provinces with a below average ENLP are located in Java and Sumatra, with only two of the sixteen below average provinces located in Eastern Indonesia (North Sulawesi and West Sulawesi; see Table 2). With regard to the absolute number of parties, the findings are similar. Overall, the average absolute number of legislative parties at the provincial level in 2009 stood at 13.3. Once again though, most provinces in Sumatra and Java had a smaller-than-average number (exceptions: North Sumatra, Bengkulu, Kep Riau, and Banten) whereas almost all provinces in Eastern Indonesia had an above-average number (only exception: North Sulawesi). Thus, it appears as if there is something like a "party political Wallace Line" as party systems in Eastern Indonesia display rather different characteristics from those in the Western parts of the archipelago.

The exact reasons for these differences are yet to be studied in detail, but they are likely to include a mixture of socioeconomic and sociocultural factors such as ethnicity and religion. There is, for example, some correlation between the Human Development Index and the ENLP at the provincial level. Crudely put, where human development is low, party system fragmentation tends to be high, and vice versa. However, this nexus between human development and the format of the party system is only true for two-thirds of Indonesia's 
thirty-three provinces while eleven provinces do not show any kind of meaningful correlation. Equally inconclusive are sociodemographic factors such as ethnicity. There is, for example, fairly little evidence that the ethnic composition of a province affects the format of the party system. This is largely in line with Aspinall's $(2011,289)$ argument that "ethnicity is losing political salience." Though there are some cases where ethnic heterogeneity correlates with high levels of party system fragmentation (for example, Papua, Central Sulawesi, or North Maluku) as well as cases where ethnic homogeneity correlates with low ENLP (for example, Bali, West Sumatra, or Yogyakarta), there are also many counterexamples where this correlation does not exist (for example, North Sulawesi, Gorontalo, Central Kalimantan, or West Nusa Tenggara). Thus, just like human development, ethnicity also appears to be influential only in some, but not in all, areas. Perhaps the most compelling influence on spatial variation is the prevalence of religious cleavages and their translation into party politics. Since this factor relates directly to key aspects of party institutionalization, such as a party's rootedness in society, cleavages and their impact on spatial variation in levels of fragmentation will be discussed further below in the section on party institutionalization.

Despite the regional discrepancies between East and West, however, there is one commonality that unites almost all the provinces across the archipelago, namely, a trend toward greater fragmentation over time. For example, a comparison of the 2004-2009 and 2009-2014 periods shows that in the overwhelming majority of provinces the share of seats for the largest party decreased in 2009 and the number of new parties in the legislature eclipsed the number of parties that were thrown out from parliament. Moreover, in the vast majority of provinces both the absolute and the effective number of legislative parties have increased in 2009. As is illustrated in Table 2 , only three provinces (Riau, West Java, and Papua) had a higher absolute number of legislative parties in 2004 than in 2009, while Jakarta and Aceh were the only two provinces to record a higher effective number of legislative parties in 2004 than in 2009. Across the thirty-two provinces for which data were available, the average absolute number of legislative parties in 2004 was 10.47 (13.33 in 2009) while the average effective number of legislative parties in 2004 was 6.08 (7.95 in 2009). Overall then, there is a clear upward trend toward more fragmentation in provincial parliaments, a trend that is even more pronounced at the district level. 


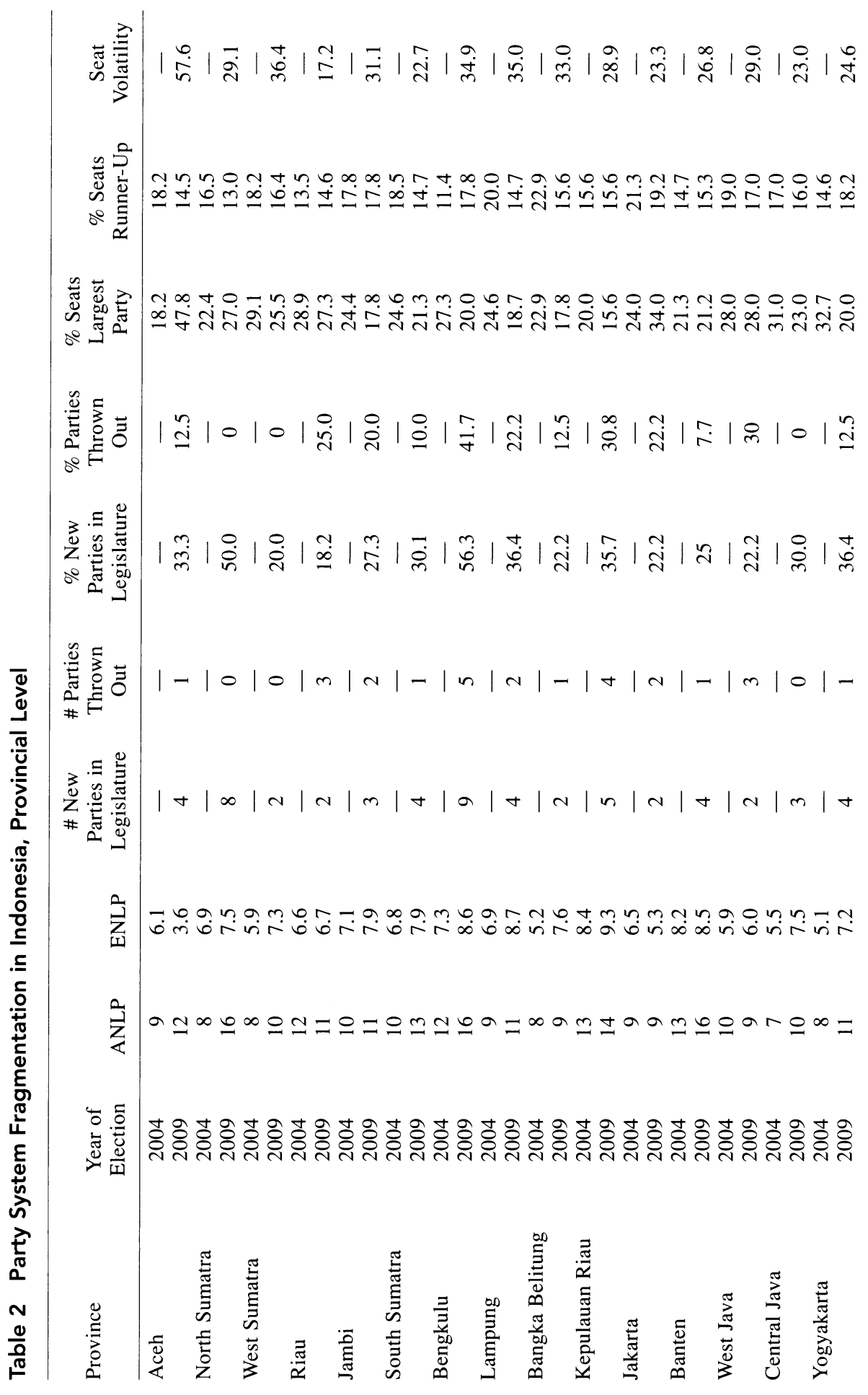




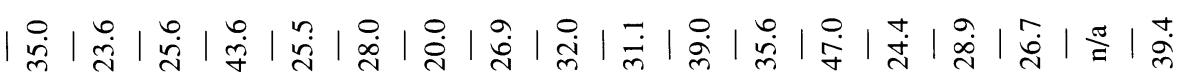

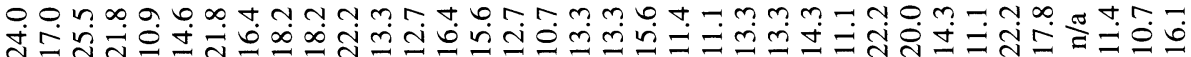

o o n m m n m

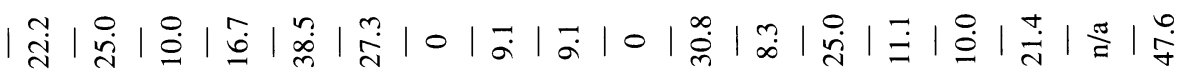

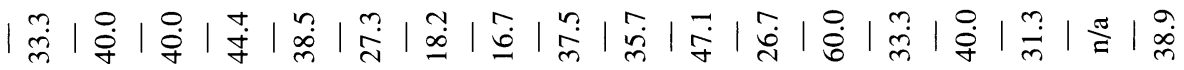

$|-| n|-| n|n| m|0|-|-| 0|+|-|n|-|-| m\left|\frac{\pi}{m}\right| 0$

$|+|+|0| \infty|n| m|n| n|0| n|\infty|+|a|+|0| n\left|\frac{\pi}{\Xi}\right| n$

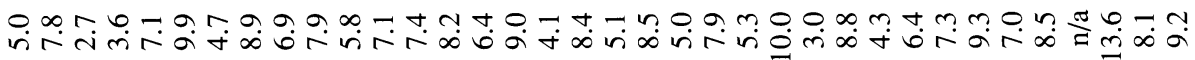

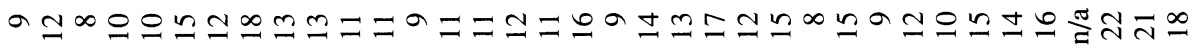

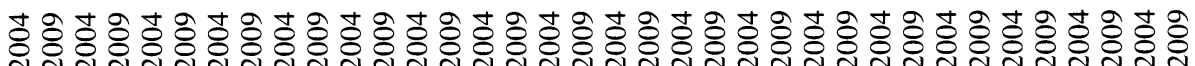

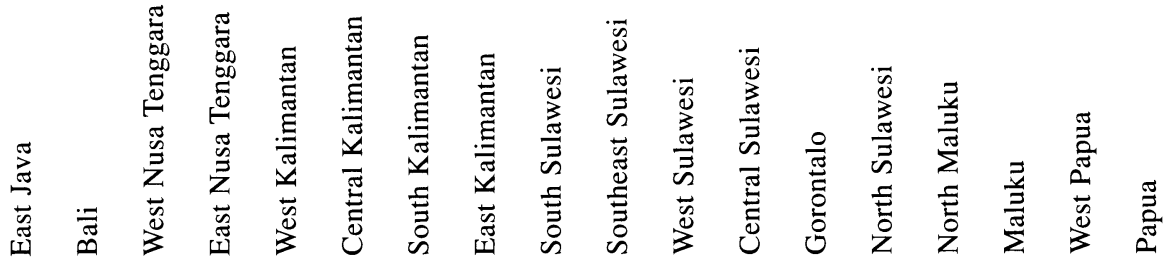


In particular, the very high levels of fragmentation in Eastern Indonesia as shown in Table 2 are replicated at the district level. Across all districts on the island of Sulawesi, for example, the average effective number of legislative parties for the 2009-2014 period is 8.7, while the average absolute number of legislative parties is 12.64 . In line with the figures from the provincial level, fragmentation is comparatively low in most districts of North Sulawesi (average ENLP 6.4), but fairly high in the majority of districts in all other provinces except Gorontalo (average ENLP of more than 9 in all the districts of Central Sulawesi, West Sulawesi, South Sulawesi, and Southeast Sulawesi). Similarly, in North Maluku the average ENLP on district level is 8.4; in Maluku it is even 11.7.

Following on from this broader picture, a more detailed account of growing district-level fragmentation over time is provided in Table 3, which illustrates average district-level developments since 1999 in all the districts of three selected provinces-North Sulawesi, Southeast Sulawesi, and Maluku. Here we can see that even though the extent of fragmentation varies among the provinces, fragmentation at the district level has, with a few exceptions, continuously increased over the years. Indeed, even in North Sulawesi, where the fragmentation indicators are generally less extreme than elsewhere, the general pattern of poor party system institutionalization is also evident.

Table 3 Party System Fragmentation at District Level: North Sulawesi, Southeast Sulawesi, and Maluku

\begin{tabular}{|c|c|c|c|c|c|c|c|c|c|}
\hline & \multicolumn{3}{|c|}{ North Sulawesi } & \multicolumn{3}{|c|}{ Southeast Sulawesi } & \multicolumn{3}{|c|}{ Maluku } \\
\hline & 1999 & 2004 & 2009 & 1999 & 2004 & 2009 & 1999 & 2004 & 2009 \\
\hline ANLP & 8.8 & 7.9 & 10.5 & 7.3 & 9.7 & 12.8 & 10.4 & 11.1 & 14.9 \\
\hline ENLP & 4.1 & 4.7 & 6.4 & 2.7 & 6.5 & 9.5 & 4.9 & 8.3 & 11.7 \\
\hline \multicolumn{10}{|l|}{ New parties } \\
\hline in legislature & - & 4.3 & 5.3 & - & 4.0 & 5.9 & - & 5.4 & 6.5 \\
\hline Parties thrown out & - & 5.3 & 2.3 & - & 2.5 & 2.9 & 一 & 5.4 & 2.5 \\
\hline \multicolumn{10}{|l|}{ New parties } \\
\hline in legislature (\%) & - & 56.9 & 48.3 & - & 41.7 & 46.1 & - & 52.8 & 43.6 \\
\hline Parties thrown out $(\%)$ & - & 59.6 & 29.3 & - & 33.6 & 28.2 & - & 52.4 & 22.4 \\
\hline Seats largest party (\%) & 41.1 & 36.1 & 29.5 & 58.2 & 30.6 & 19.9 & 36.1 & 22.5 & 15.9 \\
\hline Seats runner-up (\%) & 23.0 & 22.2 & 17.9 & 12.0 & 13.6 & 13.3 & 19.6 & 14.6 & 11.1 \\
\hline Seat volatility & - & 33.3 & 34.0 & - & 39.5 & 43.9 & - & 49.9 & 43.3 \\
\hline
\end{tabular}

Notes: All figures are average numbers across all districts and municipalities in that year. Note that the number of districts and municipalities increased from election to election due to the process of creating new administrative entities (pemekaran). For example, North Sulawesi had only five districts and municipalities in 1999, but nine in 2004 and fourteen in 2009. For Southeast Sulawesi the figures are five in 1999, ten in 2004, and twelve in 2009. Maluku had five in 1999, eight in 2004, and eleven in 2009. 
All in all, this table shows a wealth of evidence for the poor institutionalization of local party systems and the general trend toward greater fragmentation and fluidity over time. First, both the absolute and effective number of legislative parties reached unprecedented heights in 2009 across all three provinces. ${ }^{6}$ Thus, in the Indonesian case the number of parties-both absolute and effective-does provide reliable evidence for the growing fragmentation of local party systems, at both the provincial and district levels. Second, levels of volatility are high to very high at the district level, producing local parliaments in which new parties sometimes make up more than half of all the parties in the legislature. Third, the share of seats for the largest party dropped quite sharply in many areas, especially in Southeast Sulawesi and Maluku, whereas the share of seats for the second largest party remains much more stable in most places. As will be outlined below, this is closely linked to the decline of Golkar in many places, though the Indonesian Democratic Party-Struggle (Partai Demokrasi Indonesia-Perjuangan, PDIP) is also affected in some districts. Read in conjunction with the increase in the absolute and effective number of parties, it is clear that these trends are often a result of the strongest party's losing seats without being replaced by another strong party. Instead, a plethora of small clientelistic parties with no roots in society beyond the immediate networks of individual candidates filled the seats, causing high levels of fragmentation in many districts. Taken together, all these indicators provide a comprehensive account of the high levels of fluidity and fragmentation in the local party systems of Eastern Indonesia.

In the following section I will discuss some of the potential reasons for the various trends illustrated so far. In particular, I will explain why fragmentation is generally higher at the local level than at the national level, why levels of fragmentation in nearly all subnational party systems have increased so consistently over time, and why fragmentation is particularly high in Eastern Indonesia. The focus will be on the role of electoral institutions, the interplay between party and party system institutionalization, and the nature of electoral campaigning at the local level.

\section{Causes of Weak Party System Institutionalization at the Local Level}

Hicken and Kuhonta (2011) provide a useful overview of the most salient factors that may influence the way party systems develop and add important insights from their own comparative study of Asian 
party systems at the national level. Of the five sets of variables they discuss, three-the passage of time, timing or period effect, and the characteristics of the previous regime-are either not very helpful or simply irrelevant for the provincial and district case studies presented here. The previous regime type, for instance, was the same for all of these parliaments. The passage of time is very short for all local parliaments, with the number of elections that have been held ranging from one to three depending on the year of the creation of the province or district. In any case, longevity as a variable has no explanatory power in the case of Indonesian local parliaments as party systems have, contrary to theoretical expectations, destabilized rather than stabilized. Finally, there is no strong evidence that the timing effect has had an impact. Regardless of whether district parliament elections were first held in 1999, 2004, or 2009, the highest ENLPs were almost always recorded for 2009. At the same time, levels of volatility in places that had their first elections in 1999 show no distinctively different pattern from those that had their first election only in 2004.

In the following section, therefore, I focus primarily on the other two variables discussed by Hicken and Kuhonta-political institutions and politicized social cleavages-but I also broaden the discussion by considering factors such as patterns of party organization, the changing nature of political campaigning, and the role of the media. I establish clear causal links between these factors and the generally very high levels of local party system fragmentation and the consistent trend toward ever-increasing levels of fragmentation in many areas. Explaining spatial variance, however, is a bit more complex. As will be outlined below, historical and sociocultural factors such as religion and its translation into party political loyalties appear to play a role, but more comprehensive (possibly quantitative) analysis would need to be done to elucidate more precisely why fragmentation has been particularly high in Eastern Indonesia.

\section{Electoral Institutions}

The observed trend toward greater fragmentation of local party systems needs to be seen against the background of Indonesia's decentralization process. Since the beginning of this process, political positions in the regions have carried much more prestige than during the centralized New Order era (Erb and Sulistiyanto 2009; Schulte Nordholt and van Klinken 2007). Institutional change in the form of far- 
reaching decentralization measures therefore provided important incentives for people to join political parties and seek office in local parliaments. This corresponds broadly with Chhibber and Kollman's (2004) argument that greater authority for subnational governments facilitates fragmentation. ${ }^{7}$ However, the enhanced attractiveness of a political career at the local level does not explain why so many aspiring local politicians have chosen to join small rather than large parties. Nor does it provide any obvious reasons why so many voters have supported these politicians by voting for them. Decentralization-induced fragmentation is often caused by the emergence of regional parties founded specifically to represent the interests of localized constituencies (Thorlakson 2007), but in Indonesia no regional parties exist as party laws require all Indonesian parties to be national in scope. ${ }^{8}$ It is therefore imperative to look at more specific aspects of institutional change including the impact of changes to the electoral rules since 1999 .

Scholars of party system formation have long acknowledged the significant potential of electoral rules to shape the nature of party systems (Cox 1997; Hicken 2009; Reilly 2006; Sartori 1976; Taagepera and Shugart 1989). While there are dozens if not hundreds of different types of electoral systems, a basic differentiation can be made between majoritarian systems that aim to provide the foundations for stable governments and more permissive systems such as proportional representation that seek to foster stronger linkages between parties and voters. The inherent risk with permissive electoral rules is of course that they become too permissive, facilitating high levels of fragmentation and instability under the pretext of providing a fair and proportional level of popular representation. To prevent fragmentation, countries that use a form of proportional representation often apply electoral thresholds to limit the number of parties in parliament.

With regard to Indonesia, the most decisive factor in shaping the different trends between the national party system and the various local party systems has indeed been the evolution of the electoral rules that have regulated the conduct of Indonesian elections since 1999. Like many other young democracies, Indonesia too has experimented with a range of electoral systems since it began its democratization process (Horowitz 2013). Elections for executive positions, for example, have changed from indirect elections through parliaments (both national and local) to direct elections since 2004. In its parliamentary elections, meanwhile, Indonesia initially used a closed 
list proportional representation system with a low electoral threshold of 2 percent in 1999, then a partially open list system with a slightly higher yet still fairly low electoral threshold of 2.5 percent in 2004, and then an open list system with a parliamentary threshold of 2.5 percent in 2009. District magnitude has been progressively reduced since 1999 in an effort to make it harder for small parties to win seats, but as Choi (2010) has demonstrated by calculating the effective number of parties based on vote shares at the constituency level (rather than seats in parliament), these changes were utterly ineffective.

In the context of this article, the single most important reform was the change to the implementation of the threshold regulation in 2009. In the two previous elections in 1999 and 2004, parties that failed to meet the threshold were still allowed to enter parliament, but they were not allowed to contest the following election under the same name. After this regulation was first applied in 1999, several parties reconstituted themselves under only slightly altered names and then competed again in the 2004 election. The most prominent example is the Prosperous Justice Party (Partai Keadilan Sejahtera, PKS), which had initially participated in the 1999 election under the name Justice Party (Partai Keadilan, PK). After winning only 1.4 percent of the vote and thus failing to meet the electoral threshold, it entered parliament with seven legislators and then renamed itself PKS ahead of the 2004 election. In 2004, this mode of applying a threshold was retained, leading to the consequence that several parties that failed to meet the now slightly raised threshold once again reregistered for the 2009 election only under marginally altered names. In 2009, however, the threshold regulation was applied in a more conventional fashion, disqualifying any party that failed to meet the threshold from sending members to parliament. The impact was felt immediately as only nine out of the thirty-eight competing parties met the 2.5 percent barrier.

Interestingly, however, this reform to the threshold regulation was not implemented at the subnational level. Small parties and local politicians had lobbied hard for provincial- and district-level politics to be left untouched by the changing threshold regulations, arguing that local political conditions were different from the national level and that a uniform application of the threshold would undermine the spirit of decentralization. The success of these lobbying efforts, combined with the switch to a fully open party list system, paved the way for a significant divergence in the trajectories of the national and local parliaments. While the national parliament saw a reduction in both 
absolute and effective numbers of parties, the overwhelming majority of local parliaments experienced the reverse trend in 2009. However, while electoral institutions can explain why the broader trends between the national and local levels differ, they cannot account for the sometimes extreme extent of fragmentation in Eastern Indonesia. As has been shown before, fragmentation in this part of the country is much higher than in the Western parts, even though all provinces have used the same electoral institutions in all elections.

\section{How Party Institutionalization Impacts Party System Institutionalization}

The impact of institutional change cannot be overstated, but permissive rules that provide incentives for certain political behavior alone cannot explain why both politicians and voters have responded to these incentives in the ways they did. Where party systems are built around strongly institutionalized parties with effectively organized party apparatus and deep roots in society, voters could be expected to shun the new incentives to vote for new or small parties and continue to support the parties they have grown accustomed to. But if parties are poorly institutionalized, both party members and voters will feel more easily inclined to switch their loyalties.

In Indonesia most parties are indeed poorly institutionalized. They lack strong enforceable rules to regulate their internal affairs, are notoriously short of financial resources, and only have a very small base of loyal supporters (Tomsa 2008). Increasing dealignment is visible in the consistent loss of voter support for the core parties and the growing number of swing voters (Tomsa 2010). These trends are not only mirrored but arguably even more pronounced at the local level, especially in Eastern Indonesia, where party roots have always been less established than on Java. Though there is growing awareness among politicians that elections can no longer be won by just distributing some money on the morning of election day (the socalled serangan fajar), local party boards are still largely inactive in between election periods.

Parties do of course spring into action during election times. However, rather than demonstrating their strength, they often descend into destructive internal bickering over candidatures and positions, often exposing themselves to public ridicule. This is particularly true during elections for local executives where parties operate as crucial gatekeepers in the nomination process for prospec- 
tive governors, mayors, and district heads. Most parties nowadays use public opinion surveys conducted by an ever-growing number of consultants to determine their candidates, but it is also not uncommon that parties grant the nominations either to members of dominant clientelistic networks or simply to external candidates who are willing to pay the local party boards huge amounts of money to secure the nomination (Buehler and Johnson Tan 2007). Either way, competence, merit, or service to the party is rarely considered to be an asset in these struggles for local power. But the rules that determine "electability" are fluid, leaving room for disagreements and diverging interpretations. As a result, prospective candidates who lose out in the nomination process of one party often jump ship to other parties. Frustrated supporters of losing would-be candidates often then vent their anger at the party and are unlikely to support that party in the next election. ${ }^{9}$

The ubiquity of splits, defections, and ill-discipline among party members at the local level, as well as the inability by party bosses and boards to solve internal strife through widely accepted regulations, highlights deficiencies in key dimensions of party institutionalization, namely, the internal organization of the party apparatus and the rootedness of the party in a fixed social milieu (Mainwaring and Scully 1995; Randall and Svåsand 2002). It also highlights the causal connection between party institutionalization and party system institutionalization. As Hicken and Kuhonta $(2011,2)$ point out, "institutionalized parties ... play an important role in party system institutionalization, since the stability of interparty competition must necessarily depend on the presence of cohesive and ideological organizations creating a setting for patterned electoral contests." Most of Indonesia's parties are neither cohesive nor ideological, and the absence of these attributes is particularly pronounced at the local level where "party shopping" (Aspinall 2013, 40) by local notables and other powerful figures has become an all too familiar pattern.

Fragmentation within local party systems, then, occurred as an almost logical consequence of the combined effects of poorly designed electoral institutions and weak party institutionalization. Once the institutional setting had provided the incentives, it became clear that the bigger parties' failure to invest in party building had resulted in a double dilemma. On the one hand, the parties lacked sufficient topdown management to enforce internal discipline from the center to the regions while, at the same time, they lacked genuine political values that could link ordinary members and supporters at the grassroots more 
tightly to the party. Thus, in the lead-up to the 2004 and 2009 elections many of the parties that had done well in 1999 were unable to prevent large-scale defections as many aspiring local politicians who lacked the resources to compete with the established party elites took advantage of the open list system by joining smaller parties where they could immediately get a leading position in the party structure or a candidature for parliament. In the elections these candidates effectively represented themselves, banking on the strength of their personal prestige while using the party merely as a symbolic vehicle necessary to compete in the election. To this end, growing party system fragmentation at the local level was a result of both electoral system change as well as the failure of the big parties to, as Panebianco (1988) once put it, become valuable in and of themselves.

Significantly, the extent of party institutionalization also helps explain the spatial variation in fragmentation between Eastern and Western Indonesia. In Java and, to a somewhat lesser extent, Sumatra local party systems are only moderately fragmented because they are still shaped to some degree by the prevalence of the politicized religious cleavages that once characterized Indonesian politics in the 1950s. In Eastern Indonesia, by contrast, social cleavages are far less "particized" (Ufen 2013), not least because this region was barely touched by the first phase of party development in the 1950s. During the New Order, this party political vacuum was quickly filled by Golkar, which became so dominant that in some areas of Sulawesi it recorded election wins with more than 90 percent of the vote. When Golkar's electoral hegemony came to an end in 1999, the party was initially successful in defending its dominant position in many local parliaments, thereby providing a stabilizing effect to the party system (Croissant and Voelkel 2012, 249). Subsequent elections, however, revealed that Golkar's strength was never built on deep roots in society but mostly on a dense web of clientelistic networks (Tomsa 2008). As competitive elections became the norm in post-Suharto Indonesia, more and more locally powerful officeholders who had acted as important vote getters for Golkar in the past abandoned the former regime party and joined smaller parties.

Table 4 shows that by 2009 , Golkar's strength was fading even in some of its best-established strongholds in North and Southeast Sulawesi. In other provinces its share of seats in provincial parliaments (Dewan Perwakilan Rakyat Daerah, DPRD) fell to levels similar to those in the national DPR. It is in these areas in Eastern Indonesia, where Golkar once used to dominate the party system at 
will but now struggled to adapt to the changing dynamics of local politics, that fragmentation increased most dramatically because no other single party has been able to take the place Golkar once occupied. Instead, a multitude of small parties seized the opportunity, establishing small isolated power bases for individual politicians who more often than not were former Golkar officials who had lost out in internal power struggles within the former regime party.

These dynamics are not unique to Sulawesi and adjacent islands, but they are certainly more common in the eastern parts of Indonesia than in Java and Sumatra where small parties have found it more difficult to challenge the bigger parties due to the latter's deeper roots and better organizational infrastructures. A look at the extent and regional variation of the parties' territorial penetration lends further evidence to this argument. In 2004, there were only six truly nationalized parties that won seats in thirty or more provincial parliaments (Golkar, PDIP, and PKS as well as the Democratic Party [Partai Demokrat, PD], the National Mandate Party [Partai Amanat Nasional, PAN], and the United Development Party [Partai Persatuan Pembangunan, PPP]), while at the other end of the spectrum there were fifteen small parties that only won seats in less than ten provincial parliaments. Significantly, nine out of these won most of their seats in the Eastern provinces. For example, a party like the Indonesian Justice and Unity Party (Partai Keadilan dan Persatuan Indonesia, PKPI) won seats in just seven provincial parliaments, but only two of these were in Western Indonesia (Aceh and Bengkulu) while five were in Eastern Indonesia (Papua, Maluku, South Sulawesi, Central Sulawesi, and North Sulawesi). Similarly, the Pelopor Party only won seats in three provincial parliaments, and all of these were

Table 4 Golkar's Seat Share in Selected Provincial and District Parliaments (in percentage)

\begin{tabular}{lllllr}
\hline Province & 2004 & 2009 & District & 2004 & 2009 \\
\hline Gorontalo & 54.3 & 24.4 & Bombana & 32.0 & 12.0 \\
South Sulawesi & 44.0 & 24.0 & Kolaka & 30.0 & 8.6 \\
West Sulawesi & 40.0 & 28.9 & Konawe South & 36.7 & 16.7 \\
Southeast Sulawesi & 37.8 & 20.0 & Kendari & 40.0 & 13.3 \\
Central Sulawesi & 37.8 & 20.0 & Sangihe & 56.0 & 28.0 \\
North Sulawesi & 37.8 & 26.7 & South Minahasa & 33.3 & 20.0 \\
East Nusa Tenggara & 38.2 & 20.0 & North Minahasa & 36.0 & 16.0 \\
West Nusa Tenggara & 27.3 & 18.2 & Western Southeast Maluku & 32.0 & 12.0 \\
\hline
\end{tabular}


located in the East (Maluku, West Sulawesi, East Nusa Tenggara). The trend was even starker in 2009 when there were twenty-one small parties with seats in fewer than ten provincial parliaments and fourteen of these won the majority of their seats in the East. ${ }^{10}$ Overall, small parties won a mere total of twenty-nine seats in the twentyone provincial DPRDs of Sumatra, Java, Bali, and Kalimantan, while fifty-five seats were won by these small parties in the twelve provinces east of the Wallace line (see Table 5).

\section{Electoral Campaigning}

The combination of poorly institutionalized parties and electoral rules that facilitate personalistic politics has implications for the nature of political campaigning, which in turn influences electoral outcomes and hence the format of the party system. Arguably, the most important development in the area of electoral campaigning in Indonesia has been the use of lavish television advertisements and the rise to prominence of professional pollsters and consultants (Mietzner 2009b; Ufen 2010). Both of these trends have entailed a massive explosion in costs and effectively excluded large parts of the population from participating in electoral competitions. The use of these new campaign techniques is most prominent in elections for executive office, at both the national and local levels, but it is now also commonplace for political parties to utilize the services of survey institutes and political consultants to select their candidates for the legislative party lists ahead of parliamentary elections. Once the campaigns get under way in earnest, however, many candidates for local parliaments still resort primarily to traditional methods of campaigning, even though there is now an ever-growing number of locally based political consultants that offer a wide range of services including public opinion surveys, performance evaluations for incumbent legislators, branding, image making, and issue identification as well as training for public debates and speechmaking.

Especially in the more remote parts of the country, candidates in local legislative elections often simply lack the financial resources to hire such professional assistance. A public opinion survey at the provincial level can cost several hundred million rupiah, and expenses for placing strategic advertisements in newspapers and local television stations can easily exceed one billion rupiah per month. Asked about the importance of elections for the local media, newspaper editors in Kendari and Manado frankly admitted that for 


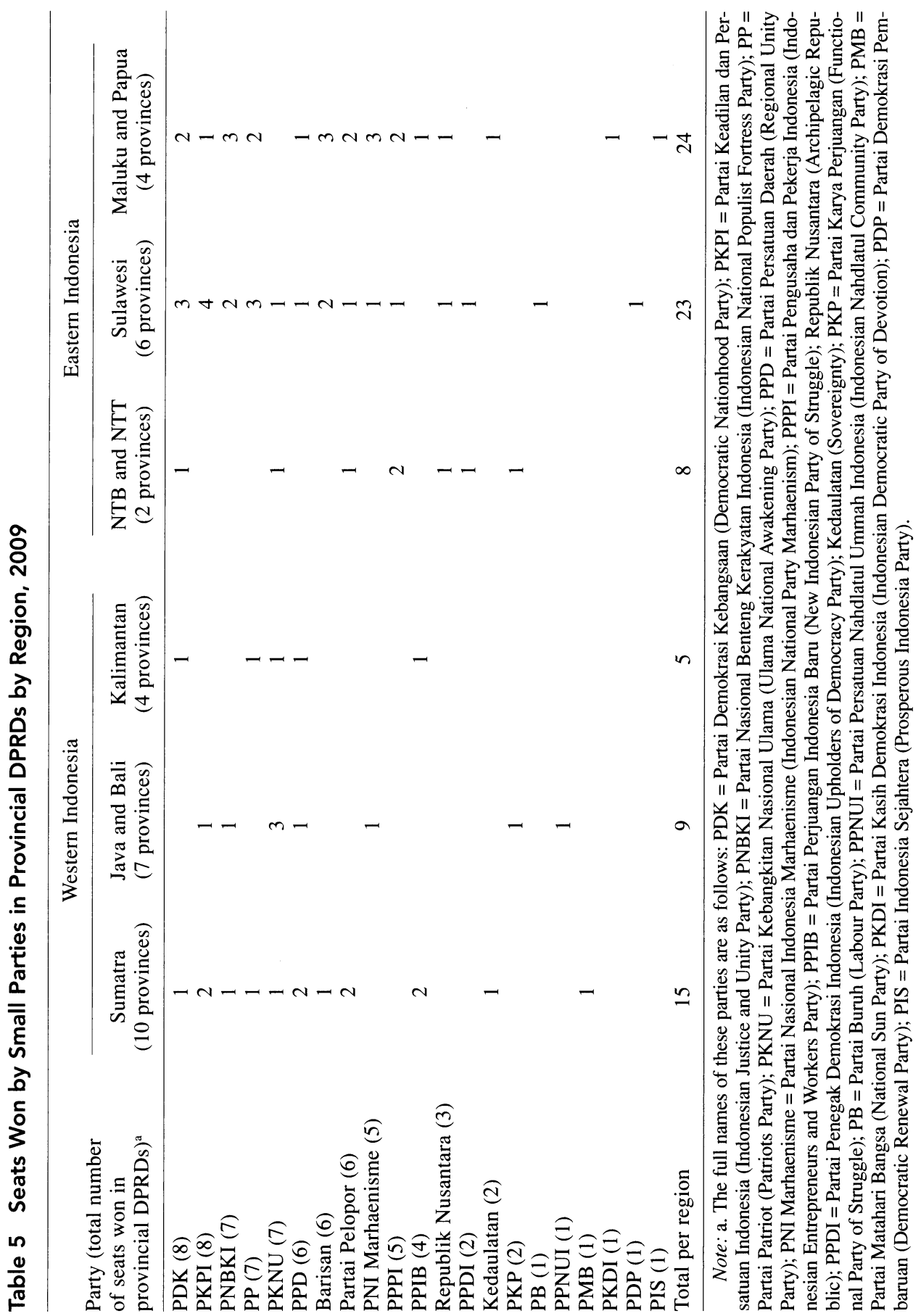


them elections are primarily business opportunities. ${ }^{11}$ Accordingly, many local candidates think twice before placing expensive advertisements in local media or engaging the help of professional consultants. Furthermore, local candidates face the additional challenge of vying for the voters' attention at the same time when candidates for the national parliament also run their campaigns. Normally, these candidates have far better financial resources at their disposal, which they can use to assemble local success teams and secure access to valuable advertising space in local media outlets. In these conditions of concurrent high-stakes political competition at various levels, it is the candidates for the district and municipality DPRDs that are usually forced to rely on more traditional means of campaigning.

Anecdotal evidence from interviews with members of local parliaments suggests that campaigning at this level is indeed still very much based on the utilization of localized clientelistic networks rather than expensive media campaigns. Candidates seek support from a broad range of local organizations such as church and mosque groups, adat organizations, neighborhood councils, and youth and sports associations. Where candidates are members of families with long-standing experience in local politics-which is often the casethey will use the family name to highlight their social standing and to expand their clientelistic networks. ${ }^{12}$ What is crucial in all this is that candidates first and foremost try to sell themselves rather than a particular program or policy, not to mention the vision of a particular party. Asked about their campaign strategies, several politicians in Sulawesi and Maluku admitted that they believed that for their supporters it did not really matter which party they represent. Accordingly, they put much more emphasis on their personal appeal than on the role of the party. This is also evident in the countless campaign posters that are plastered all over the country in the run-up to the elections. A disproportionally large amount of these posters appear to be for candidates for local DPRDs rather than national parliament, indicating again that local legislative candidates continue to rely on more traditional means of campaigning. What is striking about the posters once again is that many of them heavily promote the candidate rather than the party, even though it is mandatory for legislative candidates to include the name of their party on the poster. ${ }^{13}$

Thus, the logic of electoral competition effectively necessitates a focus on the individual rather than the party. This in turn has led to the phenomenon of party shopping, which occurs "when a local bureaucrat or businessperson who has a strong presence in a particu- 
lar locale or possesses some other mobilizational advantage (e.g., a clan affiliation, strong bureaucratic network, or simply enough money to buy his/her way to office), rather than subjecting him/herself to a number two position in a party dominated by a competitor, will simply switch party" (Aspinall 2013, 40). This phenomenon was first observed in the 2004 election when Indonesia still used the partially open list system, which required a candidate to secure a top position on the party list to have a reasonable chance of winning a seat (Tomsa 2008). In 2009, the fully open list system basically abolished this need, but many candidates still believe that they have a better chance of winning a seat if they have a top position in a small party rather than a low position in a big party. ${ }^{14}$ Once they have moved to a small party, they will run their campaigns without regard for the party they formally represent.

In essence, the campaign style used by many of these legislative candidates is merely a reaction to the electoral rules. But it is also recognition of the social reality in many parts of Eastern Indonesia. A recent survey conducted by the Indonesian Survey Institute (Lembaga Survei Indonesia 2012) in North Sulawesi and Maluku confirmed, for example, that the charisma and track record of a legislative candidate are far more important to most voters than the program of the party for which the candidate runs (see Table 6).

Moreover, it is also important to note that regular access to the local print media is by no means the norm for people in Sulawesi or Maluku, so spending huge amounts of money on expensive advertisements may not be the best use of a candidate's money. Quoting once again from the abovementioned LSI survey, only 15.8 percent of respondents in Maluku read a newspaper at least once a week. In North Sulawesi, the figure is 29.8 percent. This compares unfavor-

Table 6 What Voters Regard as "Very Important" When Voting in a Legislative Election (in percentage)

\begin{tabular}{lcc}
\hline Factors Influencing Voting Behavior & North Sulawesi & Maluku \\
\hline Charisma of the candidate & 54.8 & 63.7 \\
Track record of the candidate & 50.4 & 61.6 \\
Candidate's program (vision and mission) & 60.8 & 60.4 \\
Program of the party that nominates the candidate & 24.8 & 27.9 \\
Religious background of the candidate & 25.8 & 25.5 \\
Ethnic background of the candidate & 17.0 & 13.8 \\
Family connection with the candidate & 12.8 & 23.0 \\
\hline
\end{tabular}


ably with television, which is watched at least once a week by 92.2 percent of people in North Sulawesi and by 88.2 percent of people in Maluku but which is of little use to local legislative candidates as a medium for campaigning. Perhaps more importantly, out of the already small numbers of people who do read the newspapers, only 13.6 percent in Maluku and 22 percent in North Sulawesi read the papers primarily for news about local politics. Therefore, it is understandable that many local legislators choose to ignore the media as a means of campaigning and prefer traditional canvassing, door-todoor conversations, and publicly visible posters and banners. These methods reinforce the message to the voter that the candidates primarily seek to sell themselves and that parties are secondary. After the elections, the parliaments then reflect this reality. In the words of Aspinall $(2013,41)$, "local representative bodies merely [represent] individual leaders and their networks rather than collective interests or programs that can be connected to national-level politics."

\section{Conclusion}

Taken together, the three factors outlined above have had a massive impact on the development of Indonesia's local party systems. To explain the difference with the increasingly consolidated national party system, the single-most important factor has certainly been the absence of a parliamentary threshold regulation, which made it easy for small parties that failed to win seats at the national level to win seats in local parliaments. The effects of this poorly designed part of the electoral laws were further exacerbated over time as the electoral system was transformed from a closed list PR system to an open list PR system. This gradual institutional change provided crucial additional incentives for both politicians and voters to choose small parties over the established parties, thus explaining not only the general differences between the national and the local levels, but also the consistent increase over time in the number of parties in local parliaments. The effects of the electoral system were further reinforced by the changing nature of electoral campaigning in Indonesia. Nationallevel campaigns have become increasingly professional and expensive since 2004, narrowing the chances of smaller parties to reach out to voters. In local parliamentary elections, however, this professionalization of campaigning is yet to replace the traditional networkbased campaigning that has long dominated local elections. Unsurprisingly, candidates for smaller parties have found it much easier to 
compete at the local level than at the national level, thus further contributing to the growing differences between party system institutionalization at the national and the local level.

If the general differences between the national and local party systems and the consistent rise in local party system fragmentation can be attributed to the combined effect of electoral institutions and the changing nature of electoral campaigning, the reasons for the spatial differences between local party systems in Eastern and Western Indonesia are slightly less straightforward. In some areas, high levels of party system fragmentation appear to be influenced by the degree of human development while in others ethnic fragmentation correlates with fragmentation in the party system. However, there are also many counterexamples of provinces where party system fragmentation is apparently not influenced by either human development or ethnic fragmentation.

More significant appears to be the prevalence of religious cleavages and their translation into party politics. Although today's parties are nowhere near as deeply rooted in distinct social milieus as their predecessors of the 1950 s, cleavages based on religious worldviews do retain a certain degree of salience in contemporary Indonesian party politics (Mietzner 2013; Ufen 2013). The differences between the party systems in the Eastern and Western parts of the country, however, indicate that this link between religious cleavages and the party system is primarily confined to Java, where it is reflected in the ongoing though gradually declining strength of larger parties and a comparatively low degree of fragmentation. In most parts of Eastern Indonesia, on the other hand, parties lack the historical heritage from the 1950 s and possess neither organizational infrastructures nor value-infused roots in society. In many ways, party politics in these areas is more reminiscent of the extremely fragmented party landscapes in neighboring Papua New Guinea and parts of Melanesia (Fraenkel and Aspinall 2013) than Java or Sumatra. More research will need to be done to establish to what extent and in what manner cleavage structures affect local party system fragmentation.

Overall, the analysis of Indonesia's local party systems highlights two broader problems inherent in Indonesia's democratization process. First, decentralization-a key component of the democratization process-has made local parliaments neither more efficient nor more accountable. Despite the creation of institutional incentives that enhanced the attractiveness of local office, local parties and party systems remain poorly institutionalized because inadequately 
conceptualized reforms designed to devolve power to the local level did not entail specific measures to concurrently strengthen local party organizations. As a result, efficiency is compromised by the sheer numbers of legislative parties, while accountability is weakened by the high levels of volatility. Second, the analysis here provides a new perspective on Indonesian party politics, which cautions against too much optimism after some recent works tended to emphasize the more positive developments at the national level. Clearly, the high levels of fragmentation in local party systems reveal that significant weaknesses in organizational and programmatic development continue to exist, especially in Eastern Indonesia where parties are still failing to fulfill some of their most basic political functions. For example, fragmentation here is not at all indicative of enhanced representation of societal interests or the kind of conflict-mitigating multipolar fluidity that Horowitz (2013) has described. Where parties merely represent individuals or family clans rather than broader communities, they contribute little, if anything at all, to conflict management between social groups. Instead, they simply render parliamentary processes meaningless and paralyze regional development.

The 2014 election will slow down and even reverse some of the trends discussed in this article. While volatility is likely to remain fairly high, the absolute number of parties (and probably also the effective number of parties) in many districts will decrease due to revisions made to the electoral laws in 2012. This latest election law stipulates that any party that fails to pass an increased threshold of 3.5 percent at the national level will not be considered for the seat allocation at the provincial, municipal, and district levels (Buehler 2012). Moreover, registration requirements for political parties were tightened substantially, leading to the disqualification of most of the smaller parties on the grounds of lacking organizational infrastructure in the regions. In early 2013, the General Election Commission (Komisi Pemilihan Umum, KPU) announced that only twelve parties would be allowed to run in the 2014 election. ${ }^{15}$ The impact of this KPU decision was felt immediately at the local level, where politicians who had previously run for small parties were now scrambling to be accommodated by those parties that were declared eligible for 2014. In all three provinces visited for this article, members from established parties like Golkar, PDIP, PAN, PD, PKS, and Hanura stated that they had been approached by incumbent members of provincial and district DPRDs in need of a new electoral vehicle. At the same time, several parties admitted that they were now actively trying to poach members from the small par- 
ties that will not be allowed to contest the next election. Thus, it is clear that at least in some respects party systems will stabilize as a result of institutional change. However, just like at the national level, this stabilization will be built on porous foundations without institutionalized parties (Tomsa 2010). The following five years will show if, and if yes, to what extent, such an institutionally engineered stabilization will have an impact on the performance of local parliaments and the future prospects of local party organizations.

Dirk Tomsa is a senior lecturer in the Department of Politics, Philosophy, and Legal Studies at La Trobe University, Melbourne. He is the author of various articles, books, and book chapters on Indonesian politics including Party Politics and Democratization in Indonesia: Golkar in the Post-Suharto Era (2008) and Party Politics in Southeast Asia: Clientelism and Electoral Competition in Indonesia, Thailand, and the Philippines (coedited with Andreas Ufen, 2013).

\section{Notes}

This article was first presented at the 2013 Association for Asian Studies Conference in San Diego where Allen Hicken and other panelists and participants provided valuable comments. A revised version was then prepared during a fellowship at the GIGA Institute of Asian Studies in Hamburg. Special thanks to Andreas Ufen for hospitality during that time and for feedback on this article. Finally, I would like to thank the three anonymous reviewers and the $J E A S$ editorial board for their constructive feedback. The research for this article was funded by the Australian Research Council through grant DP1096149.

1. See, for example, Dewi Fortuna Anwar's comments in Suara Pembaruan (2012).

2. Stable party systems with strong parties of course also exist in nondemocratic regimes (for example, in Malaysia or Singapore); however, they are not a quintessential feature of authoritarianism. A functioning modern democracy, on the other hand, is inconceivable without reasonably wellinstitutionalized parties and party systems due to the parties' key role in providing electoral accountability and representation of societal interests.

3 . Volatility is measured by calculating the net changes in the percentage of seats (or votes) won or lost by all parties from one election to another divided by two (Pedersen 1979). The effective number of parties index, which measures the relative strength of parties in a party system, is measured by calculating the ratio of the sum of the squared seat (or vote) proportion of all parties in the system (Laakso and Taagepera 1979).

4. The share of the five biggest parties decreased dramatically to just 66 percent in 2004 and then a little further to 61 percent in 2009.

5. Provincial data for the first democratic election of the post-Suharto period in 1999 were only available for fifteen provinces and were therefore excluded from the analysis here. It is, however, noteworthy that out of these fifteen provinces, twelve had the lowest ENLP in 1999 and all of them had 
the highest in 2009. Thus, while incomplete, these figures do lend further weight to the trends described in this article.

6. A closer look at individual districts reveals that there was only one municipality where the ANLP was not the highest in 2009 (Tomohon) and only three districts where the ENLP in 2009 was lower than in previous years (Kepulauan Talaud, Kolaka North, and Buru). Individual district data are available from the author.

7. See Schakel (2013) for an overview of how the extent and nature of regional authority as well as other variables affect congruence between national and local elections in established democracies.

8. Stipulations for party branch offices have been progressively tightened from election to election. The 2008 party law that formed the regulatory basis for the 2009 election, for example, stated that parties must have regional chapters in two-thirds of all provinces and in two-thirds of the total number of regencies/municipalities in the province. The only exception was Aceh, where local parties are allowed to exist as part of the special autonomy framework.

9. Such outbreaks of violent frustration occur frequently, but are usually short-lived and locally confined. In the run-up to the 2013 gubernatorial election in Maluku, for example, both PDIP and Golkar offices were ransacked by marauding supporters of politicians who had failed to secure a nomination for the election.

10. Two new parties, Gerindra and Hanura, immediately won seats in nearly all provincial parliaments in 2009 , bringing the number of truly nationalized parties to eight. In between the truly nationalized parties and the tiny parties discussed in this section is a relatively small group of moderately nationalized parties with a medium level of territorial penetration in 2004 and 2009, respectively: these include PKB (seats in twenty-three provinces in both 2004 and 2009), PBB (twenty-two and twenty), PBR (twenty-three and sixteen), PDS (eighteen and fifteen), PKPB (nine and thirteen), and PPRN (ten in 2009).

11. Interviews with representatives from Kendari Pos, Manado Pos, and Tribun Manado newspapers, October 2011 and February 2013.

12. Local politics is rife with attempts at building dynasties (Buehler 2013). Powerful families often have members in both the local executive and parliaments as well as other influential organizations and, sometimes, national parliament and party boards. Examples in the provinces studied here include the Sarundajang, Mangindaan, and Baramuli families in North Sulawesi and the Tuasikal and Latuconsina families in Maluku.

13. For a detailed analysis of Indonesian election campaign posters, see Fox (2013).

14. Results from the national elections vindicate this. Out of 560 legislators elected to the national parliament, only 30 won their seats from a list place lower than fourth (Tomsa 2010, 144).

15. Initially, only ten parties passed the KPU's verification process, but the number was later revised after a successful legal challenge from two smaller parties (Detiknews 2013). 


\section{References}

Ambardi, Kuskridho. 2008. "The Making of the Indonesian Multiparty System: A Cartelized Party System and Its Origin." PhD diss., Ohio State University.

Aspinall, Edward. 2011. "Democratization and Ethnic Politics in Indonesia: Nine Theses." Journal of East Asian Studies 11, 2: 289-319.

—. 2013. "A Nation in Fragments." Critical Asian Studies 45, 1: 27-54.

Buehler, Michael. 2012. "Indonesia's New Election Law to Stall Reform Post-2014." Oxford Analytica Daily Brief, May 1.

- 2013. "Married with Children." Inside Indonesia 112 (April-June).

Buehler, Michael, and Paige Johnson Tan. 2007. "Party-Candidate Relationships in Indonesian Local Politics: A Case Study of the 2005 Regional Elections in Gowa, South Sulawesi Province." Indonesia 84: 41-69.

Chhibber, Pradeep, and Ken Kollman. 2004. The Formation of National Party Systems: Federalism and Party Competition in Canada, Great Britain, India, and the United States. Princeton, NJ: Princeton University Press.

Choi, Jungug. 2010. "District Magnitude, Social Diversity, and Indonesia's Parliamentary Party System from 1999 to 2009." Asian Survey 50, 4: 663-683.

Cox, Gary W. 1997. Making Votes Count: Strategic Coordination in the World's Electoral Systems. New York: Cambridge University Press.

Croissant, Aurel, and Philip Voelkel. 2012. "Party System Types and Party System Institutionalization: Comparing New Democracies in East and Southeast Asia." Party Politics 18, 2: 235-265.

Detiknews. 2013. "PBB \& PKPI Lolos ke Pemilu 2014, KPU Jangan Sembrono Hadapi Pencalegan." March 25.

Erb, Maribeth, and Priyambudi Sulistiyanto, eds. 2009. Deepening Democracy in Indonesia? Direct Elections for Local Leaders (Pilkada). Singapore: Institute of Southeast Asian Studies.

Fox, Colm. 2013. "Personal Charisma and Electoral Campaigning in Local Indonesian Elections." Paper presented at the annual meeting of the Association for Asian Studies, San Diego, March 21-24.

Fraenkel, Jon, and Edward Aspinall. 2013. Comparing Across Regions: Parties and Political Systems in Indonesia and the Pacific Islands. CDI Policy Papers on Political Governance. Canberra: Centre for Democratic Institutions.

Hadiz, Vedi R. 2010. Localizing Power in Post-Authoritarian Indonesia: A Southeast Asia Perspective. Stanford, CA: Stanford University Press.

Hicken, Allen. 2009. Building Party Systems in Developing Democracies. New York: Cambridge University Press.

Hicken, Allen, and Erik Martinez Kuhonta. 2011. "Shadows from the Past: Party System Institutionalization in Asia." Comparative Political Studies 44, 5: 572-597.

Horowitz, Donald L. 2013. Constitutional Change and Democracy in Indonesia. Cambridge: Cambridge University Press.

Johnson Tan, Paige. 2006. "Indonesia Seven Years After Soeharto: Party System Institutionalization in a New Democracy." Contemporary Southeast Asia 28, 1: 88-114. 
2013. "Anti-Party Attitudes in Southeast Asia." In Party Politics in Southeast Asia: Clientelism and Electoral Competition in Indonesia, Thailand and the Philippines, ed. Dirk Tomsa and Andreas Ufen, 80-100. London and New York: Routledge.

Laakso, Markku, and Rein Taagepera. 1979. "The Effective Number of Parties: A Measure with Application to Western Europe." Comparative Political Studies 12, 1: 3-27.

Lembaga Survei Indonesia. 2012. Survei Kerukunan Umat Beragama di Provinsi Sulawesi Utara dan Maluku. Unpublished public opinion survey. Jakarta: LSI.

Lindberg, Staffan. 2007. "Institutionalization of Party Systems? Stability and Fluidity Among Legislative Parties in Africa's Democracies." Government and Opposition 42, 2: 215-241.

Mainwaring, Scott P., and Timothy R. Scully. 1995. "Introduction: Party Systems in Latin America." In Building Democratic Institutions: Party Systems in Latin America, ed. Scott P. Mainwaring and Timothy R. Scully, 1-34. Stanford, CA: Stanford University Press.

Mietzner, Marcus. 2008. "Comparing Indonesia's Party Systems of the 1950s and the Post-Suharto Era: From Centrifugal to Centripetal InterParty Competition.” Journal of Southeast Asian Studies 39, 3: 431-453.

- 2009a. Indonesia's 2009 Elections: Populism, Dynasties and the Consolidation of the Party System. Sydney: Lowy Institute.

- 2009b. "Political Opinion Polling in Post-Authoritarian Indonesia: Catalyst or Obstacle to Democratic Consolidation?" Bijdragen tot de Taal-, Land en Volkenkunde, 165, 1: 95-126.

- 2013. Money, Power, and Ideology: Political Parties in PostAuthoritarian Indonesia. Singapore: NUS Press.

Panebianco, Angelo. 1988. Political Parties: Organization and Power. Cambridge: Cambridge University Press.

Pedersen, Mogens N. 1979. "The Dynamics of European Party Systems: Changing Patterns of Electoral Volatility." European Journal of Political Research 7, 1: 1-26.

Protsyk, Oleh, and Andrew Wilson. 2003. "Centre Politics in Russia and Ukraine: Patronage, Power, and Virtuality.” Party Politics 9, 6: 703-727.

Randall, Vicky, and Lars Svåsand. 2002. "Party Institutionalization in New Democracies." Party Politics 8, 1: 5-29.

Reilly, Benjamin. 2006. Democracy and Diversity: Political Engineering in the Asia-Pacific. New York: Oxford University Press.

Sartori, Giovanni. 1976. Parties and Party Systems: A Framework for Analysis. Cambridge: Cambridge University Press.

Schakel, Arjan H. 2013. "Congruence Between Regional and National Elections." Comparative Political Studies 46, 5: 631-662.

Schulte Nordholt, Henk, and Gerry van Klinken, eds. 2007. Renegotiating Boundaries: Local Politics in Post-Suharto Indonesia. Leiden: KITLV.

Shabad, Goldie, and Kazimierz M. Słomczyński. 2004. "Inter-Party Mobility Among Parliamentary Candidates in Post-Communist East Central Europe." Party Politics 10, 2: 151-176. 
Slater, Dan. 2004. “Indonesia's Accountability Trap: Party Cartels and Presidential Power After Democratic Transition." Indonesia 78: 61-92.

Suara Pembaruan. 2012. "Partai Terlalu Banyak Tak Produktif untuk Negara Demokratis." February 16.

Taagepera, Rein, and Matthew S. Shugart. 1989. Seats and Votes: The Effects and Determinants of Electoral Systems. New Haven, CT: Yale University Press.

Thorlakson, Lori. 2007. “An Institutional Explanation of Party System Congruence: Evidence from Six Federations." European Journal of Political Research 46, 1: 69-95.

Tomsa, Dirk. 2008. Party Politics and Democratization in Indonesia: Golkar in the Post-Suharto Era. New York: Routledge.

— 2010. "The Indonesian Party System After the 2009 Elections: Towards Stability?" In Problems of Democratisation in Indonesia: Elections, Institutions and Society, ed. Edward Aspinall and Marcus Mietzner, 141-159. Singapore: Institute of Southeast Asian Studies.

Ufen, Andreas. 2010. "Electoral Campaigning in Indonesia: The Professionalization and Commercialization After 1998." Journal of Current Southeast Asian Affairs 29, 4: 11-37.

- 2013. "Lipset and Rokkan in Southeast Asia: Indonesia in Comparative Perspective." In Party Politics in Southeast Asia: Clientelism and Electoral Competition in Indonesia, Thailand, and the Philippines, ed. Dirk Tomsa and Andreas Ufen, 40-61. New York: Routledge.

Wolinetz, Steven B. 2006. "Party System Institutionalization: Bringing the System Back In." Paper prepared for the annual meeting of the Canadian Political Science Association, Saskatoon, May 29-June 1. http://www.cpsa-acsp.ca/papers-2007/Wolinetz.pdf. 